
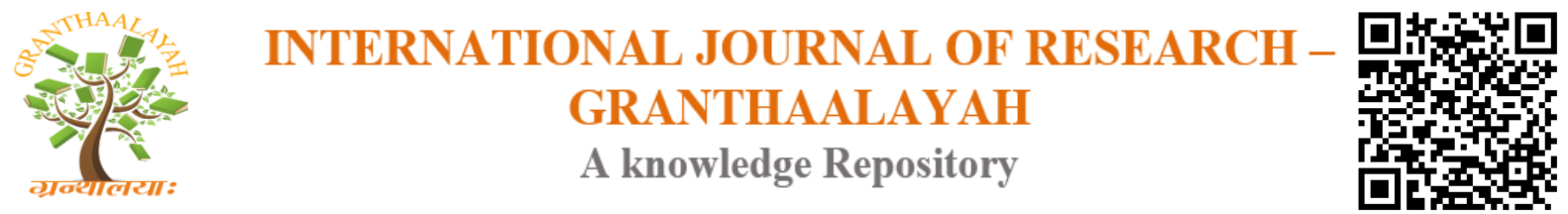

Management

\title{
A STUDY ON ADVERTISING STRATEGY OF FAST MOVING CONSUMER GOODS (FMCG) SECTOR IN INDIA - WITH SPECIAL REFERENCE TO TRICHY DISTRICT
}

\author{
Dr. K.Alex ${ }^{* 1}$, M. Mary Suthanthira Malar ${ }^{2}$ \\ ${ }^{* 1}$ Associate Professor of Commerce, St.Joseph's College, (Autonomous), Tiruchirappalli - 2, \\ India \\ ${ }^{2}$ Assistant Professor of Commerce, Holy Cross College, (Autonomous), Tiruchirappalli - 620 \\ 002, India
}

\begin{abstract}
Advertising developed mainly in twentieth century. The development of technology and research brought sophistication in advertising in recent decades. It has developed significantly after Second World War. After 1950, television became the important medium of advertising. Advertising business changed with the business environment. It is rarely a stable business. Fast Moving Consumer Goods (FMCG) are more in demand and frequently purchased by customers. These goods include all Consumable goods (other than pulses and grains) and consumers buy at regular intervals in small quantities. SWOT Analysis applied to measures the Advertising Strategy of FMCG Sector. Both Primary and Secondary sources of data were utilized for the study. Primary data was collected by means of administering a questionnaire to the customers and advertising manager. Secondary data had been collected from various publications, periodicals, journals, etc. Convenience sampling technique was used for the survey. Questionnaire filled by the selected respondents. The sample size selected is 200 . The study concluded that the companies are used the media as a mode of promotion for the FMCG products and tough competition is being faced by the company in market, media planners should be more careful in giving message to the customers.
\end{abstract}

Keywords: FMCG; Advertisement Strategy; SWOT Analysis; Promotions and Advertisement Effectiveness.

Cite This Article: Dr. K.Alex, and M. Mary Suthanthira Malar. (2017). "A STUDY ON ADVERTISING STRATEGY OF FAST MOVING CONSUMER GOODS (FMCG) SECTOR IN INDIA - WITH SPECIAL REFERENCE TO TRICHY DISTRICT." International Journal of Research - Granthaalayah, 5(7), 631-638. 10.29121/granthaalayah.v5.i7.2017.2172.

\section{Introduction}

Advertising developed mainly in twentieth century. The development of technology and research brought sophistication in advertising in recent decades. It has developed significantly after 
Second World War. After 1950, television became the important medium of advertising. Advertising business changed with the business environment. It is rarely a stable business. At present in India the advertising business is booming. There are now many advertising clubs and advertising agencies in India. Advertising is an important form of communication and its basic responsibility is to deliver the message to the target audience. It is a very important tool of promotion.

\section{Fast Moving Consumer Goods}

Fast Moving Consumer Goods (FMCG) are more in demand and frequently purchased by customers. These goods include all Consumable goods (other than pulses and grains) and consumers buy at regular intervals in small quantities. Main items in this category are detergents, soaps, shaving products, shampoos, toothpastes and brushes, packed food stuffs, household accessories, creams, oils, tea, coffee etc. The major players in the markets are HUL, Nestle, P \& G, Colgate, ITC, Nirma, Britania, Amul, Emami, Marico and Dabur.

\section{SWOT Analysis of FMCG Sector}

\section{Strengths}

1) Low operational cost

2) Presence of the established distribution networks in both urban and rural areas

3) Presence of well-known brands in FMCG sector

\section{Weakness}

1) Lower scope of investing in technology and achieving economies of scale, especially in small sector

2) Low exports levels

3) Counterfeit Products. These products narrow the scope of FMCG products in rural and semi-urban market.

\section{Opportunities}

1) Untapped rural market

2) Rising income levels i.e. increase in purchasing power of consumers

3) The Large domestic market population is over one billion.

4) Export potential

5) High consumer goods spending

\section{Threats}

1) Removal of import restrictions resulting in replacing of domestic products

2) Slowdown in rural demand

3) Tax and regulatory structure

\section{Scope of the Study}

This present study helps in exploring the advertising strategy of FMCF Sector in India. It covers the advertising as a tool of promotion. It will study the relation of advertising and media planning and its impact on effectiveness of promotion activities. Indian FMCG sector and its leading companies will be study. In brief, promotion, advertising, major decision areas, media 
planning and advertising effectiveness in leading companies in Indian market will be covered in scope of the study.

\section{Objectives of the Study}

1) To understand major decision areas like mission, message media, money and measuring the advertising strategy.

2) To find out the practices adopted by the leading companies regarding advertising strategy.

3) To suggest ways on the basis of finding to improve advertising and media planning function to claim more effectiveness in promotion activities.

\section{Research Design}

Before investigating the types of research designs it is important to understand the role and purpose of research design. It's also required to know what type of research design is formulated. The main purpose of the present study is "A study on advertising strategy of FMCG sector in India" - with special reference to Tiruchi District. To study the research topic, out of descriptive, experimental and exploratory the descriptive research is suitable.

\section{Methodology}

Both Primary and Secondary sources of data were utilized for the study. Primary data was collected by means of administering a questionnaire to the customers and advertising manager. Secondary data had been collected from various publications, periodicals, journals, etc.

\section{Sampling Method}

Convenience sampling technique was used for the survey. Questionnaire filled by the selected respondents.

\section{Sample Size}

To represent every segment of the universe the sample size included sufficient in number. For higher accuracy of the data very small and large sample sizes are avoided. The sample size selected is 200. Large sample size has been avoided due to its difficult to manage and small size of sample is avoided due to improper representation of the universe and one sided result.

\section{Statistical Tools and Data Analysis}

Data have been analysed and tested with the help of tables, percentage, chi-square analysis, and analysis of variance test has been used.

\section{Hypothesis}

1) There is no significant difference in the sex of the respondents and media where consumers come across shorter and frequent advertisements in a day.

2) There is no significant difference in the age of the respondents and media where consumers come across longer and non-frequent advertisements in a day. 
3) There is no significant difference in the educational qualification of the respondents and effectiveness of medium of advertising to communicate the consumers.

4) There is no significant difference in opinion as to main tasks of advertising manager.

5) There is no significant difference in the factors considered in choosing the medium for advertising as part of strategic media planning.

Table 1: Table showing relationship between sex and media where consumers come cross

\begin{tabular}{|l|l|l|l|l|}
\hline SEX/MEDIA & Electronic Media & Print Media & Trade Fairs \& Exhibitions & Total \\
\hline Male & 55 & 45 & 25 & 125 \\
\hline Female & 30 & 11 & 10 & 51 \\
\hline Total & 85 & 56 & 35 & 176 \\
\hline
\end{tabular}

Source: Primary Data

The above table reveals that the relationship between the sex and media where consumers come across shorter and frequent advertisements in a day. Out of 176 respondents, 85 respondents are short and frequent advertisement comes on electronic media, 56 respondents say it is in print media and remaining 35 respondents say trade fairs and exhibitions. While applying chi-square test, the relationship has been found.

\section{Hypothesis}

There is no significant difference in the sex of the respondents and media where consumers come across shorter and frequent advertisements in a day.

Table 1a:

\begin{tabular}{|l|l|l|l|}
\hline Calculated Value & Tabulated Value & Degrees of freedom & Level of significance \\
\hline 4.02 & 5.99 & 2 & $5 \%$ Level \\
\hline
\end{tabular}

The calculated value is less than the tabulated value. So, the hypothesis is accepted. Hence, there is no significant difference in the sex of the respondents and media where consumers come across shorter and frequent advertisements in a day.

Table 2: Table showing relationship between age and media where consumers come cross

\begin{tabular}{|l|l|l|l|l|l|}
\hline AGE/CATEGORY & Hoarding & TV \& Radio & Posters & Newspaper & Total \\
\hline Below 20 & 7 & 4 & 8 & 12 & 31 \\
\hline $21-30$ & 5 & 3 & 15 & 20 & 43 \\
\hline $31-40$ & 4 & 5 & 7 & 10 & 26 \\
\hline $41-50$ & 6 & 26 & 4 & 4 & 40 \\
\hline Above 50 & 5 & 13 & 2 & 16 & 36 \\
\hline Total & 27 & 51 & 36 & 62 & 176 \\
\hline
\end{tabular}

Source: Primary Data

The above table shows that the relationship between the age and media where consumers come across longer and non-frequent advertisements in a day. Out of 176 respondents, 62 customers believe that a newspaper is the medium which show longer but not frequent advertisement in a day. 51 respondents say that TV and radio, 36 respondents say the source is posters and 
remaining 27 respondents say the medium is hoardings. While applying chi-square test, the relationship has been found.

\section{Hypothesis}

There is no significant difference in the age of the respondents and media where consumers come across longer and non-frequent advertisements in a day.

Table 2a:

\begin{tabular}{|l|l|l|l|}
\hline Calculated Value & Tabulated Value & Degrees of freedom & Level of significance \\
\hline 52.04 & 21 & 12 & $5 \%$ Level \\
\hline
\end{tabular}

The calculated value is more than the tabulated value. So, the hypothesis is rejected. Hence, there is significant difference in the age of the respondents and media where consumers come across longer and frequent advertisements in a day.

Table 3: Table showing relationship between educational qualification and effectiveness of medium of advertising to communicate the consumers

\begin{tabular}{|l|l|l|l|l|}
\hline $\begin{array}{l}\text { EDUCATIONAL } \\
\text { QUALIFICATION/CATEGORY }\end{array}$ & Newspaper/Magazines & Radio & Television & Total \\
\hline SSLC Level & 6 & 4 & 5 & 15 \\
\hline HSC Level & 4 & 12 & 18 & 34 \\
\hline Graduate & 12 & 25 & 32 & 69 \\
\hline Post Graduate & 22 & 11 & 25 & 58 \\
\hline Total & 44 & 52 & 80 & 176 \\
\hline
\end{tabular}

Source: Primary Data

The above table indicates the relationship between educational qualification of the respondents and effectiveness of medium of advertising to communicate the consumers. Out of 176 customers, 80 respondents say that TV is the more effective medium, 50 respondents say that it is radio and 46 respondents say that newspaper and magazines are effective medium to communicate the consumers. While applying ANOVA test, the relationship has been found.

\section{Hypothesis}

There is no significant difference in the educational qualification of the respondents and effectiveness of medium of advertising to communicate the consumers.

Table 3a:

\begin{tabular}{|l|l|l|l|l|l|}
\hline Source of variation & Sum of Squares & D.f. & Mean Square & F & 5\% sig.(t.v.) \\
\hline Between Groups & 178.67 & 2 & 89.34 & & \\
\hline Within Groups & 824.00 & 9 & 91.56 & 1.02 & 19.385 \\
\hline Total & 1002.67 & 11 & & & \\
\hline
\end{tabular}

Source: Compiled by the researcher

The above table indicates that significant value is 19.385 greater than the calculated value. So, the hypothesis is accepted. Hence, there is no significant difference in the educational 
qualification of the respondents and effectiveness of medium of advertising to communicate the consumers.

\section{Hypothesis}

There is no significant difference in opinion as to main tasks of advertising manager.

Table 4: Task of advertising manager

\begin{tabular}{|l|l|l|l|l|l|}
\hline Task & $\begin{array}{l}\text { Observed } \\
(\mathbf{O i})\end{array}$ & $\begin{array}{l}\text { Expected } \\
(\mathbf{E i})\end{array}$ & $(\mathbf{O i - E i})$ & $(\mathbf{O i - E i})^{\mathbf{2}}$ & $(\mathbf{O i - E i})^{\mathbf{2}} / \mathbf{E}$ \\
\hline $\begin{array}{l}\text { Adverting budget } \\
\text { Decision }\end{array}$ & 4 & 4.8 & -0.80 & 0.64 & 0.13 \\
\hline $\begin{array}{l}\text { Advertising } \\
\text { research }\end{array}$ & 3 & 4.8 & -1.80 & 3.24 & 0.68 \\
\hline $\begin{array}{l}\text { Advertising timing } \\
\text { Decision }\end{array}$ & 5 & 4.8 & 0.20 & 0.04 & 0.01 \\
\hline Media planning & 9 & 4.8 & 4.20 & 17.64 & 3.68 \\
\hline $\begin{array}{l}\text { Setting advertising } \\
\text { Objectives }\end{array}$ & 3 & 4.8 & -1.80 & 3.24 & 0.68 \\
\hline Total & 24 & & & & 5.17 \\
\hline
\end{tabular}

Source: Primary Data cum compiled by the researcher

According to above table indicates the task of advertising manager. Out of 24 managers, each 3 managers say setting advertising objectives and advertising research is main task of advertising manager, 4 managers say of medium planners of FMCG companies think that advertising budget decision is main task of advertising manager, 5 manager say them think that advertising timing decision is main task of advertising manager and majority of 9 manager say that media planning is main task of advertising manager. While applying chi-square test, the opinion of the advertising manager has been found.

The calculated value is less than the table value (9.49). So, the hypothesis is accepted. Hence, there is no significant difference in opinion as to main tasks of advertising manager.

\section{Hypothesis}

There is no significant difference in the factors considered in choosing the medium for advertising as part of strategic media planning.

Table 5: Factors considered in choosing the medium

\begin{tabular}{|l|l|l|l|l|l|}
\hline \multicolumn{1}{|c|}{ Factors } & Observed (Oi) & Expected (Ei) & $(\mathbf{O i}-\mathbf{E i})$ & $(\mathbf{O i}-\mathbf{E i})^{\mathbf{2}}$ & $(\mathbf{O i - E i})^{\mathbf{2}} / \mathbf{E}$ \\
\hline Cost involved & 2 & 4.8 & -2.80 & 7.84 & 1.63 \\
\hline Effectiveness & 3 & 4.8 & -1.80 & 3.24 & 0.68 \\
\hline Medium availability & 2 & 4.8 & -2.80 & 7.84 & 1.63 \\
\hline Medium coverage & 5 & 4.8 & 0.20 & 0.04 & 0.01 \\
\hline All the above & 12 & 4.8 & 7.20 & 51.84 & 10.80 \\
\hline Total & 24 & & & 14.75 \\
\hline
\end{tabular}

Source: Primary Data cum compiled by the researcher 
While applying chi-square test, the opinion of the advertising manager has been found. The calculated value is more than the table value (9.49). So, the hypothesis is rejected. Hence, there is significant difference in the factors considered in choosing the medium for advertising as part of strategic media planning.

\section{Findings}

- All the respondents communicated have come across advertisements regarding FMCG products.

- Television and newspaper are main media through which customers come across advertisements.

- Televisions, newspapers, magazines and journals are top rankers in media viewed/read by customers.

- All media planner accepted that they are facing tough completion in advertising.

- Main tasks of advertising managers are media planning, scheduling and budget fixation mainly.

\section{Suggestions}

- Customers' awareness regarding advertising is very high. It should be kept in mind by companies for communication purpose.

- Use of televisions and newspapers are more planners also should use these media to reach to maximum number of viewers/readers.

- Television and radio are used by customers in evening and night. The planner should select schedule in these hours to communicate to more viewers/listeners.

- Short advertisements on TV and radio, lengthy advertisement should be given in newspapers and magazines.

- Media selection factors are proper and these should be focused more carefully by media planners. Proper selection of media would give satisfactory results.

\section{Conclusion}

This study tells that consumer behaviour, tolerate due to culture, when culture, traditions, trends and customs will be change then user change their choices. People like media advertisement rather than banners or newspapers. The consumers are mostly like the media advertisement. Through media, consumers are attracted more. So, the companies are used the media as a mode of promotion for the FMCG products and tough competition is being faced by the company in market, media planners should be more careful in giving message to the customers.

\section{References}

[1] Arens Willam F, Contemporary Advertising, 10th Edition, 2008, TMH, New Delhi.

[2] Batra, Myers \& Aaker, Advertising Management, 1st Edition, 2006, PHI, New Delhi.

[3] Chunawala, S.A, Advertising Sales and Promotion Management, 3rd Edition, 2008, HP.

[4] Jethwaney, Jain, Advertising Management, 1st Edition, 2006, Oxford, New Delhi.

[5] Morden A.R. 1991, Elements of Marketing, London, D.P. Publication Ltd. 
[6] Stafford, Faber, Advertising Promotion and New Media, 1st Edition, 2006, PHI, N.D.

[7] De Cheratony, L. (1998), The strategic Implications of Clarifying How Marketers Interpret Brands, Journal of Marketing Management, Vol.5 153-171.

[8] Latif, Abdul, Saleem, Salman and Abiden, Zain UL. (2011), Influence of Role Model on Pakistani Urban Teenager's Purchase Behaviour, European Journal of Economics, Finance and Administrative Science, Issue 31, pp.7-16.

[9] Newell, J., Marier, M. (2007), Desperately seeking opt-in: A field report from a student-led mobile marketing initiative, International Journal of Mobile Marketing, 2(2), pp.53-57. 